\title{
Nursing approach to tobacco users in primary health care
}

\author{
Abordagem do enfermeiro aos usuários tabagistas na Atenção Primária à Saúde \\ Abordaje del enfermero a los fumadores en atención primaria de salud
}

Vanderleia Soéli de Barros Zampier'

ORCID: 0000-0002-8085-4414

Marcelo Henrique da Silva"

ORCID: 0000-0002-6250-5050

Renata Evangelista Tavares Machado'

ORCID: 0000-0001-9004-3941

Rodolfo Ribeiro de Jesus'"I

ORCID: 0000-0003-4606-0802

Maria Cristina Pinto de Jesus'v

ORCID: 0000-0002-4720-0478

Miriam Aparecida Barbosa Merighi'

ORCID: 0000-0002-9705-2557

\section{ABSTRACT}

Objective: to understand the experience of nurses in the approach to tobacco users in primary health care services. Method: Qualitative, phenomenological research with 15 nurses who were interviewed between January and March 2017. Their speeches were analyzed and classified into categories. Results: the approach by nurses to tobacco users is performed in an individual and unsystematic manner and in operative groups in accordance with the principles of the cognitive-behavioral therapy. This is a complex approach due to issues related to users themselves and to human, material, and structural resources. The expectations of nurses include supporting smoking cessation and expanding the tobacco use prevention work in educational environments. Final considerations: this study points out that nurses need to use the nursing care systematization in coordination with the recommendations of policies aimed at tobacco use control to perform their role in the promotion, control, and reduction of health complications in tobacco users.

Descriptors: Smokers; Nursing; Professional Practice; Primary Health Care; Qualitative Research.

\section{RESUMO}

Objetivo: compreender a experiência do enfermeiro na abordagem aos usuários tabagistas na Atenção Primária à Saúde. Método: pesquisa qualitativa, fenomenológica, com 15 enfermeiros entrevistados entre janeiro e março de 2017. Os depoimentos foram analisados e organizados em categorias. Resultados: a abordagem dos enfermeiros ao usuário tabagista é realizada de modo individual e assistemático e em grupos operativos seguindo os princípios da terapia cognitivo-comportamental. Essa abordagem é complexa por causa de questões relativas ao próprio usuário e aos recursos humanos, materiais e estruturais. As expectativas dos enfermeiros incluem apoiar a cessação do tabagismo e expandir o trabalho de prevenção do uso do tabaco em espaços educativos. Considerações finais: aponta-se a necessidade de o enfermeiro apropriar-se da sistematização da assistência de enfermagem articulada às recomendações das políticas voltadas para o controle do tabagismo, com vistas a cumprir seu papel na promoção, no controle e na diminuição dos agravos à saúde dos usuários tabagistas.

How to cite this article:

Zampier VSB, Silva MH, Machado RET, Jesus RR, Jesus MCP, Merighi MAB. Nursing approach to tobacco users in primary health care. Rev Bras Enferm. 2019;72(4):948-55. doi: http://dx.doi.org/10.1590/0034-7167-2018-0397

Corresponding Author:

Maria Cristina Pinto de Jesus E-mail: mariacristina.jesus@ufjf.edu.br

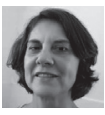

Submission: 06-05-2018 Approval: 01-26-2019

\section{RESUMEN}

Objetivo: Comprender la experiencia del enfermero en el abordaje a los fumadores en atención primaria de salud. Método: Investigación cualitativa y fenomenológica con 15 enfermeros entrevistadas entre enero y marzo de 2017. Testimonios analizados y organizados en categorías. Resultados: El acercamiento de las enfermeras al fumador se realiza de forma individual y asistemática y en grupos operativos siguiendo los principios de la terapia cognitivo-conductual. Este enfoque es complejo debido a cuestiones relacionadas con el fumador y con los recursos humanos, materiales y estructurales. Las expectativas de las enfermeras incluyen apoyar la cesación tabáquica y expandir el trabajo de prevención del tabaquismo en entornos educativos. Consideraciones finales: Se señala la necesidad de que las enfermeras adecuen la sistematización de la atención de enfermería articulada a las recomendaciones de las políticas de control del tabaquismo, cumpliendo su rol en la promoción, control y reducción de los problemas de salud de los fumadores.

Descriptores: Fumadores; Enfermería; Práctica Profesional; Atención Primaria de Salud; Investigación Cualitativa. 


\section{INTRODUCTION}

Smoking is considered a major public health problem, representing the main preventable cause of early morbidity and mortality. Tobacco use caused the death of 100 million people in the last century, and this number may reach 1 billion in the $21^{\text {st }}$ century. Smoking is included in the major preventable factors for noncommunicable diseases, such as cancer, diabetes, and cardiovascular and respiratory diseases ${ }^{(1)}$.

Data of the Surveillance System of Risk and Protective Factors for Chronic Diseases, via telephone survey - Vigitel 2016, in Brazilian capital cities showed that the prevalence of tobacco use ranged from $5.1 \%$ in Salvador to $14 \%$ in Curitiba. The highest rates of incidence of smokers were observed among men in Curitiba (17.8\%) and among women in São Paulo (12.1\%). The lowest rates of incidence of smokers among men were observed in Salvador (6.8\%) and among women in São Luís (2.3\%). The frequency of tobacco use was lower among individuals with more years of formal education, and was particularly high among men and women with up to eight years of formal education ( $17.5 \%$ and $11.5 \%$ respectively), almost twice the frequency observed among individuals with 12 or more years of formal education ${ }^{(2)}$.

In Brazil, an intense and successful work carried out by health professionals was observed in the development of public policies and actions for smoking control. From the international movements this flow gained the Ministry of Foreign Affairs as an important ally, which strengthened and reinforced negotiations, raising Brazil to a prominent position within the Framework Convention on Tobacco Control of the World Health Organization (FCTC-WHO) ${ }^{(3)}$.

Brazil has been participating in the FCTC-WHO since 2005, and its measures make up the National Policy on Tobacco Control (NPTC). The outcomes of this policy point out a significant reduction in the prevalence of smokers and morbimortality related to the use of tobacco, such as cardiovascular diseases, chronic respiratory diseases, and lung cancer ${ }^{(4)}$.

The NPTC contributed to the standardization of the approach to smokers in public health services, of which primary health care (PHC) is considered the most favorable scenario for this approach. Due to its attributes (first access, comprehensiveness, longitudinality, and coordination of care), PHC is the first point of contact of the population with the health system, having the responsibility of supporting and following up the tobacco-addicted user in relation to the treatment of this chronic condition ${ }^{(5)}$.

In this context, this study highlights the importance of the work of health professionals in the approach to tobacco users to provide support to those who want to quit smoking. As a member of the health team and due to their professional specificities (including as a health educator), nurses play a critically relevant role in the NPTC. These professionals may use a variety of interventions focused on tobacco use control, such as advice in the short, basic, and intensive approaches and motivational interview, contributing to the achievement of satisfactory outcomes in relation to the improvement of rates of smoking cessation and maintenance of short and long term abstinence( ${ }^{(6)}$.

Considering the issues related to tobacco addiction, which involves physical, psychological, and behavioral components, approaching tobacco users represents a challenge to nurses, particularly because the FCTC-WHO and the NPTC recommend actions focused on smoking cessation which, in practice, are not always successful. Based on the above, the following research questions were formulated: What is it like for nurses to approach tobacco users in the context of PHC? What are their expectations when approaching these users? Uncovering the subjectivity involved in the nurses' approach to tobacco users may help professionals to rethink and reconfigure the strategies of intervention that support them in the performance of tobacco use prevention and control activities.

\section{OBJECTIVE}

To understand the experience of nurses in the approach to tobacco users in the context of primary health care.

\section{METHOD}

\section{Ethical aspects}

The present study was conducted in accordance with the ethical precepts specified in the Resolution 466/2012 of the National Health Council, and was approved by the Human Research Ethics Committee of the Nursing School of the University of São Paulo.

\section{Study type and theoretical-methodological framework}

This is a qualitative study, using the approach of the social phenomenology of Alfred Schütz. This framework presents theoretical assumptions that contribute to the understanding of the human experience in the social world. In this world, individuals coexist and share the same time and space so that some conscious processes of some individuals represent significant elements to others. This similar flow of consciousness propitiates the social construction of the individuals and affects their relationships in a context marked by intersubjectivity. The set of knowledge is made up of previous experiences as well as those acquired by means of information culturally transmitted by parents, masters, and people with direct contact. It places the human being in a given situation called the biographical situation. Thus, the approach of nurses to tobacco users is permeated with experiences in the social world that may be apprehended from the theory of human motivation. This theory includes the "reasons why" (related to past and present experiences) and the "reasons for" (projects of new experiences) ${ }^{(7)}$.

The research followed the steps recommended by the Consolidated Criteria for Reporting Qualitative Research (COREQ) ${ }^{(8)}$.

\section{Study site}

The study site included the PHC units of a city in the state of Minas Gerais, Brazil, with a population of 516,247 inhabitants, estimated in 563,769 by 2017 , according to the Brazilian Institute of Geography and Statistics (IBGE) in 2010. Its territorial area corresponds to $1,435,749 \mathrm{~km}^{2}$, and it has 165 health institutions linked to the Brazilian Unified Health System (SUS, as per its acronym in Portuguese). Of these, 62 are basic health units (BHUs) ${ }^{(9)}$. In these $\mathrm{BHUs}$, there are about 160 family health teams, in which nurses are the mandatory members. 


\section{Data source}

Fifteen nurses of both sexes participated in the study. All of them worked in basic health units for at least two years and had received training on cognitive-behavioral therapy provided by the Tobacco Control, Prevention, and Treatment Service (Secoptt, as per its acronym in Portuguese) with a focus on the work with tobacco-addicted users, especially the operative group.

\section{Data collection}

Speeches were collected through phenomenological interviews. This type of interview allowed the participants to describe face-to-face to the researcher the meaning of the experience approached in the study. The researcher asks and the interviewee answers, describing their experience regarding the studied phenomenon ${ }^{(10)}$. Data collection was conducted between January and March 2017 by the lead researcher, duly qualified to conduct the phenomenological interviews.

To contact the participants, the researcher accessed the list of health services of the city that was part of the Secoptt. Using the list, those in charge of the BHUs were contacted via telephone; the aim of the study was clarified and a date to attend the health units was scheduled. After accessing the units, the researcher approached the nurses to invite them to participate in the study. Those who voluntarily agreed to participate in the study scheduled a date, time, and place of their preference to provide the speeches.

The collection of speeches was facilitated by the existing relationship between the researcher and the participants, as the researcher was a nurse of one of the BHUs, part of the health care network of the studied scenario. It is important to mention that the service in which the researcher worked was not included in the study.

The interviews were recorded in audio, had an average duration of 40 minutes, and were conducted by the researcher. Prior to the collection of the speeches, the researcher explained to the participants the aims of the study, the ethical aspects involved, and the need to sign the free and informed consent form.

A semi-structured script containing the following questions was used to guide the interview: Talk about your experience in approaching tobacco users. What are your expectations in relation to this approach? Data for the characterization of the participants were also collected: age, tobacco use and dependence, time of consumption, and number of cigarettes per day, time of service in the $\mathrm{BHU}$, and the period in which the professional received training to approach tobacco users.

The participants were individually interviewed in their workplace, in a comfortable, private room that allowed them to discuss the investigated theme without the presence of other people and without interruptions. All the collected speeches were included in the study. The number of participants was defined based on the principles of saturation for qualitative research, which considers as ideal the sample that reflects, in quantity and intensity, the multiple dimensions of the investigated phenomenon and seeks the quality of the actions and interactions throughout the research process ${ }^{(11)}$.

In order to secure the anonymity of the participants, the speeches were identified by the letter "I", as in interview, followed by the Arabic numeral corresponding to the order of the interviews: I1 to I15.

\section{Data organization and analysis}

The categorization of the material was performed according to the steps adopted by social phenomenology researchers ${ }^{(10)}$ : transcription of the interviews by the lead researcher followed by careful reading of each speech in full in order to identify the units of meaning that congregate the "reasons why" and the "reasons for" of the experienced situation. The set of categories was discussed in the light of the Social Phenomenology of Alfred Schütz and other references related to the theme of the study.

\section{RESULTS}

\section{Characterization of the participants}

Most participants were female (73.3\%), aged between 31 and 58 years, mainly non-smokers; two nurses were former smokers. The training time ranged between 8 and 34 years, the time working in $\mathrm{PHC}$ ranged between 3 and 31 years, and the year of completion of the qualification to approach tobacco users ranged between 2007 and 2013.

\section{Categories}

Based on the social phenomenology of Alfred Schütz ${ }^{(7)}$, the meanings that emerged from the speeches were grouped into categories that reflect the experience of nurses in relation to the approach to tobacco users in PHC. The first two categories present the past and present of this experience (reasons why), whereas the third presents their expectations regarding future experiences (reasons for).

\section{Timely individual and group approaches based on the cognitive-behavioral therapy}

The nurses reported that the approach to tobacco users is timely and permeates the moments when they attend the $\mathrm{BHU}$, including during the performed procedures:

I use every opportunity, while measuring the blood pressure or making dressings, to approach individuals about the use of tobacco. Sometimes speaking is unnecessary, we can notice it by the smell, by the color of their lips, the color of their hands [...]. (I1)

I provide the service to tobacco users in an individual manner; I perform this approach during the visits, preventive, in the reception, while measuring the blood pressure; I always take the opportunity to talk with them. I also take advantage of campaigns like Pink October, Blue November, to raise awareness, warn about the use of tobacco [...]. (I8)

The specific approach is performed in the operative group of tobacco use control recommended by the Ministry of Health:

I received the training from the Ministry of Health to create the group; my approach is for the collective, with a focus on the cognitive-behavioral aspect. [...] four meetings, one per week. (I2)

I use the cognitive-behavioral technique in the groups; I make a question and they give me an answer. Depending on the answer 
provided, I make them aware of their current situation, I see if they can really quit smoking and move on. (16)

The last group was very nice, the doctor was trained, and coordinated the group very well; we had a good participation with 12 individuals: ten quit smoking. (17)

\section{The complexity of the approach to tobacco users}

Tobacco addiction and the need for a personal decision to quit the habit of smoking make the approach to smokers complex:

It is difficult to approach smokers [...] even because the use of tobacco involves emotional issues and, for this reason, the individual ends up making use of cigarettes. (I3)

[...] the social context greatly affects their decision making process; they often have smoker friends, and such friends will negatively interfere in their smoking cessation process. (I10)

The participants reported that a successful smoking cessation process depends primarily on the decision by the smoker:

[...] the approach must have their need as a premise. [...] we receive individuals that come to the groups without wanting to quit smoking. (12)

[...] as a nurse, I cannot say "You will quit it". They have to desire this by themselves; they have to make the decision, otherwise it is useless. (I8)

The frequent lack of nicotinic drugs that are part of the pharmacological treatment, the incompatibility of service hours of the BHUs and availability of the tobacco users to attend the services were also mentioned as factors that hamper the approach by nurses:

[...] sometimes I find it difficult to match the schedule of the smokers group with the availability of the tobacco users, particularly with men, because of their working hours. (I12)

[...] there is a lack of drugs. [...] for this period, now, I have not received the quantity that I had ordered, so it was not possible to provide the treatment. (I13)

The absence of professionals of other areas of knowledge was also pointed out as hampering factors in this approach, as well as the high rate of turnover of physicians and the lack of continuous training:

[...] the individual approach was not covered in my education and in the training provided by the Ministry of Health [...] I feel the need to know more about the individual approach; I have read about it, but I have never been trained, for example, to conduct the nursing visit exclusively to tobacco smoker patients. I only know the group approach, so I think it is somewhat limited. (I5)

Our problem here is related to the turnover rate: a doctor stays for six months, goes away, and another one comes; when we think the smoker group work is about to start, the doctor goes away; this greatly impairs the process. (19)
If we had a psychologist, I think it would be nice; the units that have the social worker, great, it helps, but those that do not have it need support from the Social Assistance Reference Center. (114)

\section{Support to users to quit smoking}

The main expectation of nurses in relation to the approach to tobacco smokers is related to supporting them with a view to smoking cessation:

My expectation is that they quit smoking, gain quality of life, present an inner change, and that the experience of quitting smoking is taught to others [...]. (16)

I hope they become aware of the need to quit smoking, but I know that this is not an easy task, it is an addiction. (I8)

Some nurses expressed the desire to expand the tobacco use prevention work, and to this end, they are planning to conduct activities in schools and other social facilities in order to prevent the early onset of tobacco use:

Although the consequences of the habit are well reported, the approach on the consequences of smoking has not been expanded in schools [...] it is necessary to create partnerships with the basic education. (14)

[...] the onset of the addiction occurs when they are very young, so we need to provide guidance in schools to prevent teenagers from smoking. (I11)

The nurses want to rely on other professionals, especially those trained to meet the psychological needs evidenced by tobacco-addicted users:

[...] / would like to have a larger team in order to be able to provide more support to individuals who want to quit smoking [...]. (I10)

We do not have a psychologist here, and this professional is of paramount importance; I think having a psychologist in the team would be very helpful. [...] I do not feel able to diagnose a psychic disorder. (I15)

\section{DISCUSSION}

The experiences of the nurses in the approach to tobacco users in PHC evidenced the intersubjective relationships that occur between these professionals and the tobacco users, and provided knowledge on the context that permeates this care.

The approach performed by nurses to tobacco users is conducted in a timely, individually manner, or in groups, based on the cognitivebehavioral therapy. According to the speeches, the individual approach to tobacco-addicted users by PHC nurses occurs in an unsystematic manner during the performance of nursing procedures. The findings of the present study are similar to the results found in an investigation conducted in Minas Gerais, Brazil, pointing out that a significant part of the BHUs of the city offered treatment for tobacco users; most actions were focused on individual consultations, waiting room activities, and operative groups ${ }^{(12)}$ 
In this perspective, this study analyzed that although the unsystematic approach aimed at quitting tobacco use represents an important awareness-raising mechanism used in the clinical practice of nurses, it does not provide systematized nursing care. When approaching tobacco users, nurses need to make use of the nursing care systematization as a way to ensure good practices of care to this population. By associating the nursing care systematization to the individual and collective approaches, nurses will be able to intensify the effect of the interventions and expand the spectrum of activities focused on tobacco users in PHC services.

The group approach, in turn, allows the exchange of experiences between participants, a therapeutic aspect that is considered of paramount importance as it greatly contributes to the smoking cessation process. As shown, the groups are based on the cognitivebehavioral therapy. The literature shows that, like the approach to users addicted to other drugs, the cognitive-behavioral approach associated with drugs helps in the smoking cessation process, being considered the best option for the treatment and control of tobacco use. In behavioral counseling, nurses promote motivation and self-efficacy of the users in order to cease the smoking habit and provide social support to remove the behavioral barriers that hamper the smoking cessation process. They inform users about the benefits of smoking cessation and support the development of skills to solve problems that arise from tobacco dependence ${ }^{(13)}$. On the other hand, although performed by most of the interviewed nurses, the approach in the operative group is restricted to the sections recommended by the NPTC without the longitudinal follow-up of the users in the BHU.

A systematic review that combined randomized trials comparing group therapy with self-help, individual counseling, and usual care, with a minimum of two group sections, and follow-up of smoker individuals for a minimum period of six months concluded that the group approach was better to help people to quit smoking than other less intensive interventions ${ }^{(14)}$. In this sense, actions to guarantee a long-term monitoring of these users are necessary to ensure support in the event of potential relapses.

According to the interviewed nurses, the approach to tobacco users is complex due to the physical and emotional dependence of tobacco, the lack of nicotinic drugs, the reduced availability of users to attend the treatment group, as well as the reduced health team and lack of continuous training.

The physical and emotional dependence resulting from the use of tobacco represents a barrier to their decision to quit smoking. A phenomenological study conducted in Brazil showed that smokers recognized themselves as addicted to nicotine and that the withdrawal symptoms made it difficult to succeed in the attempts to quit the addiction ${ }^{(15)}$. A qualitative study conducted in the USA found that smokers associated nicotine not only with the addiction to cigarettes, but also with other factors. When questioned about the effects of nicotine on the body, physiological effects such as stimulation and relaxation were mentioned. Many of them were not sure whether nicotine was harmful or harmless and/or had not reflected on this matter. Heterogeneity was observed in the beliefs of the smokers and the recognition of uncertainty about the issues related to smoking ${ }^{(16)}$.

The nurses stated that the motivation for quitting smoking must be a decision of the smoker, but this motivation is not always homogeneous. Another study conducted in the USA found that smokers who are not motivated to quit smoking represented a heterogeneous group. Health-conscious individuals, presenting a higher number of previous diseases related to the habit of smoking and high-risk perceptions of the habit of smoking, had a high rate of motivation to quit smoking in relation to the others. Other tobacco smokers with psychosocial barriers, mostly young individuals with tobacco smoker partners and other tobacco smokers at home had lower chances of never planning to quit the habit. Therefore, individualized approaches of intervention are important to motivate smoking cessation ${ }^{(17)}$.

In relation to the lack of nicotinic drugs to carry out the drug therapy, it was concluded that the work of nurses cannot be focused on the perspective that this limitation will culminate in the failure of the smoking cessation process. Despite the importance of the association of nicotine reuptake drugs and inhibitors of the desire to smoke in the approach to tobacco users, their role is to support the cessation of the habit of smoking ${ }^{(18)}$. With this understanding, the combination of drugs represents a punctual measure for tobacco users to deal with abstinence during the first days without cigarettes. With their knowledge and skills, nurses should contribute to the empowerment of users so they may keep the abstinence in the long term. They should guide them, and above all, build with them strategies to keep them focused on the cessation of the smoking habit.

In addition, as pointed out by the participants of the present study, it is important to take into account the high turnover rate among the professionals in the units as well as the lack of mechanisms that allow the implementation and continuity of the services in relation to their several attributions ${ }^{(12)}$. The training of health professionals working in $\mathrm{PHC}$ to implement interventions aimed at smoking cessation represents a tool to overcome the insufficiency of human resources and maximization of the access of tobacco smokers to the services of the health care system prepared to support the smoking cessation process ${ }^{(6)}$.

The lack of professionals duly trained to work with tobacco users was among the difficulties reported by the participants. An intervention study conducted in South Africa found that training to the approach of tobacco users may contribute to the achievement of positive outcomes in the smoking cessation process. After an 8-hour training for health professionals (physicians and nurses) approaching the individual counseling, they changed their perception about their ability and confidence to overcome barriers to the implementation of actions focused on tobacco users in relation to time-related restrictions, low rate of continuity of care, insufficient organizational culture, and lack of educational resources ${ }^{(19)}$.

Another aspect to be pointed out is the use of web resources to train professionals in the approach to the smoking habit, contributing to improve the work of nurses in smoking cessation interventions ${ }^{(20)}$, especially in the aspects: questions to the users about smoking, recommendation to quit smoking, assessment of the willingness to quit smoking, support in the cessation process, and recommendations to keep their house free of tobacco ${ }^{(21)}$.

In relation to the reports of the participants about the low frequency of users in the smoking treatment and control group, it is important to mention that in the scenario of this study the 
BHUs operated from 7:00 A.M. to 5:00 P.M., a period in which the population is usually at work, a fact that may be hindering the participation of the smokers. Access to health services has been reported as one of the major challenges and problems related to health care. PHC teams are responsible for coordinating the flow of people among the several offered health services, seeking to ensure greater equity in the access and use of the technologies and services of the health system in order to meet the healthrelated needs of the population ${ }^{(22)}$.

The biographical situation of the nurses and the knowledge available for them to work with tobacco users enable these professionals, by reflecting on their practice, to externalize their main intentions in relation to the care provided to such users. The study pointed out that the main expectation of nurses is to support tobacco users in the smoking cessation process. A qualitative study conducted in the Netherlands with 14 smokers and 9 PHC health professionals showed nurses were the preferred providers of intensive behavioral support with a focus on smoking cessation ${ }^{(23)}$.

Because they are in the $\mathrm{PHC}$ - the most appropriate level of care to the development of health promotion actions - the nurses mentioned their intention to expand the work of smoking prevention in schools and other social facilities. Due to the proximity of the family health teams to these mechanisms, the schools are considered a privileged space for the implementation of educational and awareness-raising actions ${ }^{(24)}$.

Taking into account the vulnerability to start smoking, a systematic review pointed out that behavioral interventions focused on children and young individuals at school age may prevent the habit of smoking and support smoking cessation. The meta-analysis showed that the participants of these interventions were $18 \%$ less prone to have started smoking at the end of the intervention in relation to the control group. It was concluded that a long-term follow-up should be included ${ }^{(25)}$.

The complexity of the treatment and control of drug addicts (such as tobacco) lead the nurses to mention the need to rely on a team of duly trained professionals to develop actions focused on tobacco users. This desire was pointed out by the users themselves in another phenomenological study. The cognitive-behavioral approach and the drug therapy provided by the public health system were considered insufficient to achieving the success of the treatment, so they felt the need for specialized psychological support ${ }^{(15)}$.

The incorporation of psychologists and psychiatrists in the multidisciplinary team for the follow-up of tobacco users with high levels of anxiety or presenting other psychiatric disorders was suggested by a cohort study that assessed patients of a smoking cessation program in Mato Grosso, Brazil. A specialized individualized approach may potentiate the outcomes of the cognitive-behavioral therapy, helping tobacco users to quit smoking ${ }^{(26)}$.

Although an expanded team in the BHUs to approach tobacco smokers represents an expectation of the nurses, in practice PHC policies recommend a team minimally made up of physicians, nurses, nursing technicians, and community health workers. Thus, nurses need to know and use the resources of the care network in order to ensure, whenever necessary, access of the smoker user to the psychotherapeutic care.

The lack of systematization of the approach to smoker users found in this study relates to the need to design and implement a care protocol to this population within the studied city to standardize the actions required for health promotion, disease prevention, and smoking treatment, even though the participants stated to have followed the guidelines of the NPTC. This protocol should include, among others, the recommendation for the evidence-based performance of nurses, the adoption of nursing care systematization in BHUs with a longitudinal follow-up of the participants of the operative group for smoking treatment and control, and the implementation of interventions in schools and other social facilities to prevent the early onset of the habit of smoking.

\section{Study limitations}

Limitations of this study include the fact that the perspective of the nurses about their experiences with tobacco users in the $\mathrm{PHC}$ context was restricted to the investigated social group, which may differ if conducted in different contexts. As it is characteristic of qualitative research, the results found cannot be generalized, but they make it possible to evidence the context of meanings expressed in the actions performed by the nurses in relation to the approach to tobacco users, as well as accessing their projects with a view to expanding the horizons of the care provided in the clinical practice to this social group.

\section{Contributions to the health and nursing areas}

The social phenomenology of Alfred Schütz made it possible to show that the experience of nurses in the approach to tobacco users in the PHC context adds value to the care required by this population as the discussion of this experience contributes to pointing out the need for nurses to expand the strategies of their work in accordance with the recommendations of the policies focused on smoking control in PHC. The discussion about good practices of nursing care in the approach to tobacco smokers in $\mathrm{PHC}$ within the scope of undergraduate and graduate nursing education may help nurses to play their role in the promotion, control, and reduction of health problems of tobacco users.

\section{FINAL CONSIDERATIONS}

The nursing approach to tobacco users is performed in an individual and unsystematic manner and in operative groups in accordance with the principles of the cognitive-behavioral therapy. This approach is complex due to the physical and emotional dependence of tobacco, the lack of nicotinic drugs, the reduced availability by users to attend the treatment group, and the reduced health team and lack of continuous training. The expectations of nurses include supporting smoking cessation and expanding the tobacco use prevention work in educational environments.

The results of the present investigation should be combined with other qualitative studies on the work of nurses in relation to the prevention of health complications and treatment of tobacco users in PHC in the sense of maximizing the production of scientific evidence to support health professionals and managers in the operationalization of the public health policies with a focus on this population. 


\section{REFERENCES}

1. World Health Organization. WHO global report on trends in tobacco smoking 2000-2025 [Internet]. Geneva: World Health Organization; 2015 [cited 2018 May 21]. 359 p. Available from: http://www.who.int/tobacco/publications/surveillance/reportontrendstobaccosmoking/en

2. Ministério da Saúde (BR). Vigitel Brasil 2016: vigilância de fatores de risco e proteção para doenças crônicas por inquérito telefônico: estimativas sobre frequência e distribuição sociodemográfica de fatores de risco e proteção para doenças crônicas nas capitais dos 26 estados brasileiros e no Distrito Federal em 2016 [Internet]. Brasília: Ministério; 2017 [cited 2018 May 21]. Available from: http:// portalarquivos.saude.gov.br/images/pdf/2017/junho/07/vigitel_2016_jun17.pdf

3. Teixeira LAS, Paiva CHA, Ferreira VN. The world health organization framework convention on tobacco control in the Brazilian political agenda, 2003-2005. Cad Saúde Pública [Internet]. 2017 [cited 2018 May 21];33Suppl 3(Suppl 3):e00121016. Available from: https://doi. org/10.1590/0102-311X00121016

4. Cavalcante TM, Pinho MCM, Perez CA, Teixeira APL, Mendes FL, Vargas RR, et al. Brazil: balance of the national tobacco control policy in the last decade and dilemmas. Cad Saúde Pública [Internet]. 2017 [cited 2018 May 21]; 33Suppl 3(Suppl 3):e00138315. Available from: doi:10.1590/0102-311X00138315

5. Ministério da Saúde (BR), Secretaria de Atenção à Saúde Departamento de Atenção Básica. Estratégias para o cuidado da pessoa com doença crônica: o cuidado da pessoa tabagista. Cadernos da Atenção Básica, n. 40 [Internet]. Brasília: Ministério da Saúde; 2015 [cited 2018 May 21]. 153 p. Available from: http://www.sgas.saude.ms.gov.br/wp-content/uploads/sites/105/2016/06/caderno_40.pdf

6. Aung MN, Yuasa M, Moolphate S, Kitajima T. Challenges for smoking cessation intervention as part of primary health care services in developing countries. J Smok Cessat [Internet]. 2016 [cited 2018 May 21];11(4):211-8. Available from: https://doi.org/10.1017/jsc.2014.28

7. Schütz A. Sobre fenomenologia e relações sociais. Wagner HT, editor. Petrópolis (RJ): Vozes; 2012.

8. Tong A, Sainsbury P, Craig J. Consolidated Criteria for reporting qualitative research (COREQ): a 32-item checklist for interviews and focus groups. Int J Qual Health Care [Internet]. 2007 [cited 2019 Jan 08];19(6):349-57. Available from: https://doi.org/10.1093/intghc/mzm042

9. IBGE: Instituto Brasileiro de Geografia e Estatística (Internet). Brasília: IBGE; 2018. População estimada 2017 [cited 2018 May 21 ]. Available from: http://www.ibge.gov.br

10. Jesus MCP, Capalbo C, Merighi MAB, Tocantins FR, Rodrigues BMRD, Ciuffo LL. The social phenomenology of alfred schütz and its contribution for nursing. Rev Esc Enferm USP [Internet]. 2013[cited 2018 May 21];47(3):728-33. Available from: https://doi.org/10.1590/ S0080-623420130000300030

11. Minayo MCS. [Sampling and saturation in qualitative research: consensuses and controversies]. Rev Pesq Qualit [Internet]. 2017 [cited 2018 May 21]; 5(7):1-12. Available from: https://editora.sepq.org.br/index.php/rpq/article/view/82/59 Portuguese.

12. Portes LH, Campos EMS, Teixeira MTB, Caetano R, Ribeiro LC. [Actions geared to tobacco control: a review of their implementation in primary health care]. Ciênc Saúde Colet [Internet]. 2014 [cited 2018 May 21];19(2):439-48. Available from: doi:10.1590/1413-81232014192.04702013 Portuguese.

13. Katz DA, Stewart K, Paez M, Holman J, Adams SL, Vander Weg MW, et al. “Let me get you a nicotine patch": nurses' perceptions of implementing smoking cessation guidelines for hospitalized veterans. Mil Med [Internet]. 2016 [cited 2018 May 21];181(4):373-82. Available from: https://doi.org/10.7205/MILMED-D-15-00101

14. Stead LF, Carroll AJ, Lancaster T. Group behaviour therapy programmes for smoking cessation. Cochrane Database Syst Rev [Internet]. 2017 [cited 2018 May 21];3:CD001007. Available from: https://doi.org/10.1002/14651858.CD001007.pub3

15. Jesus MCP, Silva MH, Cordeiro SM, Korchmar E, Zampier VSB, Merighi MAB. Understanding unsuccessful attempts to quit smoking: a social phenomenology approach. Rev Esc Enferm USP [Internet]. 2016 [cited 2018 May 21];50(1):71-8. Available from: http://dx.doi.org/10.1590/ S0080-623420160000100010

16. Johnson SE, Coleman B, Tessman GK, Dickinson DM. Unpacking smokers' beliefs about addiction and nicotine: a qualitative study. Psychol Addict Behav [Internet]. 2017 [cited 2018 May 21];31(7):744-50. Available from: https://doi.org/10.1037/adb0000321

17. Borrelli B, Gaynor S, Tooley E, Armitage CJ, Wearden A, Bartlett YK. Identification of three different types of smokers who are not motivated to quit: results from a latent class analysis. Health Psychol [Internet]. 2018 [cited 2018 May 22];37(2):179-87. Available from: https://doi. org/10.1037/hea0000561

18. Dantas DRG, Pinheiro AHB, Rossoni ALM, Prado LO, Barreira SN. [Smoking treatment with bupropion or varenicline in Brazil: a systematic review]. Rev Saúde Ciênc Online [Internet]. 2017 [cited 2018 May 21]; 5(1):61-75 Available from: http://www.ufcg.edu.br/ revistasaudeeciencia/index.php/RSC-UFCG/article/view/327/228 Portuguese.

19. Malan Z, Mash R, Everett-Murphy K. Qualitative evaluation of primary care providers experiences of a training programme to offerbrief behaviour change counselling on risk factors for non-communicable diseases in South Africa. BMC Fam Pract [Internet]. 2015 [cited 2018 May 21];16:101. Available from: https://doi.org/10.1186/s12875-015-0318-6

20. Sarna L, Bialous SA, Wells M, Brook J. Impact of a webcast on nurses' delivery of tobacco dependence treatment. J Clin Nurs [Internet]. 2018 [cited 2018 May 21]; 27(1-2):e91-e99. Available from: https://doi.org/10.1111/jocn.13875

21. Králíková E, Felbrová V, Kulovaná S, Malá K, Nohavová I, Roubíčková E, et al. Nurses' attitudes toward intervening with smokers: their 
knowledge, opinion and e-learning impact. Cent Eur J Public Health [Internet]. 2016 [cited 2018 May 21];24(4):272-5. Available from: https:// doi.org/10.21101/cejph.a4652

22. Damaceno AN, Bandeira D, Hodali N, Weiller TH. [Access at first contact in primary health care: integrative review]. Rev APS [Internet]. 2016 [cited 2018 May 21]; 19(1):122-38. Available from: https://aps.ufjf.emnuvens.com.br/aps/article/view/2521 Portuguese.

23. van Rossem C, Spigt M, Smit ES, Viechtbauer W, Mijnheer KK, van Schayck CP, et al. Combining intensive practice nurse counselling or brief general practitioner advice with varenicline for smoking cessation in primary care: study protocol of a pragmatic randomized controlled trial. Contemp Clin Trials [Internet]. 2015 [cited 2018 May 21];41:298-312. Available from: https://doi.org/10.1016/j.cct.2015.01.017

24. Laport TJ, Costa PHA, Mota DCB, Ronzani TM. [Perceptions and practices of professionals in primary health care in the approach of drug use]. Psic Teor Pesq Online [Internet]. 2016 [cited 2018 May 21];32(1):143-50. Available from: http://dx.doi.org/10.1590/010237722016012055143150 Portuguese.

25. Peirson L, Ali MU, Kenny M, Raina P, Sherifali D. Interventions for prevention and treatment of tobacco smoking in school-aged children and adolescents: a systematic review and meta-analysis. Prev Med [Internet]. 2016 [cited 2018 May 21];85:20-31. Available from: https://doi. org/10.1016/j.ypmed.2015.12.004

26. Pawlina MMC, Rondina RC, Espinosa MM, Botelho C. Depression, anxiety, stress, and motivation over the course of smoking cessation treatment. J Bras Pneumol [Internet]. 2015 [cited 2018 May 21];41(5):433-9. Available from: https://doi.org/10.1590/ S1806-37132015000004527 